\title{
Key to Identify Insects from Droppings of Some Insectivorous Bats of Nepal
}

\author{
Santosh Pokhrel* and Prem B. Budha** \\ Central Department of Zoology \\ Tribhuvan University, Kathmandu, Nepal \\ *E-mail; modesty_sane@yahoo.com \\ **Email: pbbudha@cdztu.edu.np
}

\begin{abstract}
Food habit of insectivorous bats was studied using fecal analysis. The fresh bat dropping samples from Mahendra cave, Pokhara and Nagarjun cave, Kathmandu were collected in March and September 2011. Bat droppings were moistened in hot water, separated into fine pieces and observed under stereoscope. The recovered insects and insect parts were mounted in slide, photographed and identified up to Order and Family level. Altogether ten insect orders viz. Coleoptera, Diptera, Hemiptera, Homoptera, Odonata, Hymenoptera, Lepidoptera, Orthoptera, Trichoptera and Thysanoptera and 25 families were identified. In addition, spider and mites were also reported. The identification key to Order and Family level has been prepared based on the studied characters compared with taxonomic characters from literature.
\end{abstract}

Key words: Insects, identification key, bats, cave, order, family

\section{INTRODUCTION}

Bats are the unique mammals due to their webbed forelimbs making them the only mammals naturally capable of true and sustained flight like birds. They have been reported from all geographical areas of the world, except Arctic, Antarctic, extreme desert areas and a few isolated Oceanic Islands (Mickleburgh et al. 2002; Huston et al. 2001) occupying diverse niches in both natural and human modified ecosystems. Insectivorous bats eat flying insects such as flies, moths and others insects and play important role in natural ecosystem. Some bats also serve as pollinators and seed dispersion of many plants. Their population is one of the best natural indicators of the health of our environment, because bats flourish where an ecosystem is healthy and stable (Jones et al. 2009). There are 53 species of bats have been reported from Nepal with highest number of insectivorous bats (48 species) and small number of fruit eating bats (5 species) (Thapa, 2010). Some insectivorous bat species prefer particular insect groups (Ades, 1995).

Bat species of Nepal have been recently assessed and included in conservation priority and listed as Critically Endangered (Ia io, Myotis csorbai), Endangered (Scotomanes ornatuss), Vulnerable (M. sicarius, Philetor brachypterus), Near Threatened (Hipposideros pomona, Murina aurata, Rhinolophus lepidus) and 18 species are still with insufficient information and designated as Data Deficient (Jnawali et al. 2011).

Food habit study could be done either by direct observation or indirect observation techniques. Individuals have been killed to analyse eaten contents of bat species in direct method, which is not preferred due to conservation priority. Indirect method includes identification of undigested food remains of fecal matters (droppings) at reasonable label, at least to Order and often to Family (Whitaker et al. 1988). Although there are sufficient information on the food habits of bats for other countries (e.g. Ross, 1967; Kunz \& Whitaker, 1983; Shiel et al. 1997; Whitaker \& Tom-Tov, 2001; Perlik et al. 2012), diet analysis of insectivorous bats of Nepal is nearly at nix with exception (Malla, 2000), however studies on population, distribution, behavior and assessments have been done by Nepalese researchers (Acharya, 2006; Baral \& Shah, 2008; Koju, 2008; SMCRF, 2010, Thapa, 2010; Jnawali et al. 2011). This work simply act as reference on the diet analysis of insectivorous bat of Nagarjun Cave (1609 m), Kathmandu and Mahendra Cave (962 m), Pokhara. Altogether eight species of insectivorous bats have been reported from these two caves including six species in Rhinolophus affinis, R. pusillus, R. macrotis, Hipposideros armiger, Megaderma lyra and Miniopterus schreibersii in Nagarjun Cave (Malla, 2000; SMCRF, 2010) and four species $R$. affinis, $R$. ferrumequinum and $H$. armiger, H. pomona (Giri, 2009; SMCRF, 2010) from Mahendra Cave.

This is the first attempt to identify insects from the insectivorous bat droppings of Nepal to fill the information gaps and provide reference materials for future researchers. 


\section{MATERIALS AND METHODS}

Bat droppings were collected from Mahendra Cave, Pokhara and Nagarjun Cave, Kathmandu. The latitude and longitude of Mahendra and Nagarjun caves lie on the geographical coordinates of $28^{\circ} 16^{\prime} 19.6^{\prime \prime} \mathrm{N}, 83^{\circ} 58^{\prime}$ $45.7^{\prime \prime} \mathrm{E}$ and $27^{\circ} 44^{\prime} 43.7^{\prime \prime} \mathrm{N}, 83^{\circ} 17^{\prime} 39.4^{\prime \prime}$ E respectively. Fresh bat droppings were collected two times by placing three white plastic sheets of $1 \mathrm{~m} \times 1 \mathrm{~m}$ size under the roosting sites of the cave for $24 \mathrm{hrs}$ within first and last week of each month of March and September, 2011. The fecal samples of each month were stored in air-tight container containing 70 percent ethanol and brought to the Central Department of Zoology, Tribhuvan University for further analysis.

Thirty dropping samples from each container were selected randomly. Samples were kept in a petri dish containing hot water and few drops of glycerol to ovoid evaporation of water vapours for 24 hours to soften the samples following the protocol (Kunz, 1988). The droppings were broken into fine pieces carefully with the help of fine dissecting needles under stereo-binocular microscope. The separated parts of insects were observed under microscope. Slides of the insect fragments viz. legs, wings, antenna, abdomen, mouth parts were prepared dehydrating samples in alcohol series and finally mounted in glycerinated gelatin or sometime in transparent nail polish. So, all together 120 pellets were analyzed from two caves of two season. The mounted parts in slides were photographed with PC-digital camera connected with computer. The slides were deposited at the Entomology Lab of the Central Department of Zoology, Tribhuvan University.

Structures and characters of recovered antennae, legs, wings, mouth parts, and other body parts of insects were studied and compared with available published papers (Ross, 1967; Kunz \& Whitaker, 1983; Whitaker et al. 1988, Shiel et al. 1997; Whitaker \& Tom-Tov, 2001) and textbooks (Vanemden, 1965; Bingham, 1975; Distant, 1977; Jacoby, 1975; Richards \& Davies, 1977 and Borror et al. 1981). All parts were identified upto higher taxonomic category viz. order and family level and an identification key was prepared based on the characters noted from the samples.

\section{RESULTS}

Altogether nine insect orders viz. Coleoptera, Diptera, Hemiptera, Homoptera, Hymenoptera, Lepidoptera, Orthoptera, Trichoptera and Thysanoptera representing 25 families were identified in the droppings of bats. In addition, other arthropod groups (spiders and mites) were also identified. Identification key based on the parts of insect orders and families recovered from bat droppings from Mahendra Cave, Pokhara and Nagarjun Cave, Kathmandu is represented in the following key.

\section{Key to identify prey insects in bat droppings}

Identification key is based on characters of insect parts recovered in bat droppings of Mahendra and Nagarjun caves. A dichotomous key to insect orders and families is represented as follows;

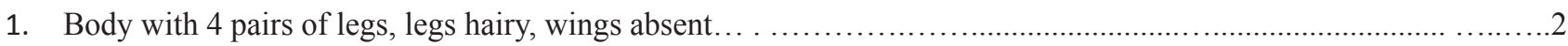

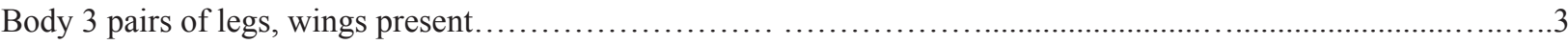

2. Body oval, four pair of legs, anteriorly directed mouth parts (Fig. 1A, B)..............................................................

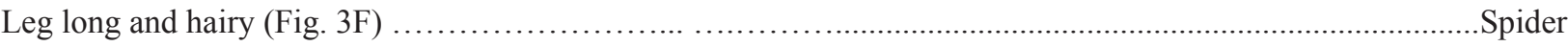

3. Scales on wing present, fecal contents often contain mass of scales spread (Fig. 2B) .......................epidoptera

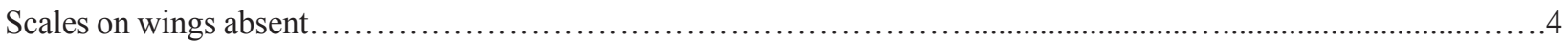

4. Wing hard or leathery and colourful body...... Coleoptera (Fig. 2L) or Heteroptera (Fig. 2K) ...........................5

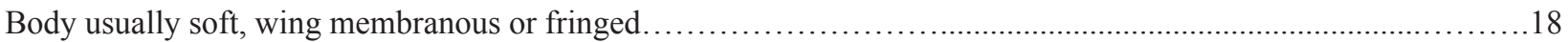

5. Tarsi with 4-5 segments, tarsal claws present (Figs. 3 J, P) without spine, antennae varied shaped viz. lamellate (Fig.

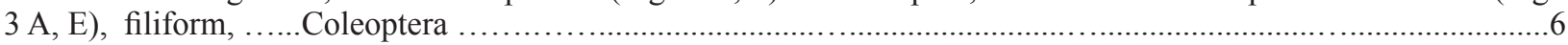

Tarsi 2 or 3 segmented, hemelytra present, long hairy or spiny leg Hemiptera/Heteroptera .............................14

\section{Coleoptera}

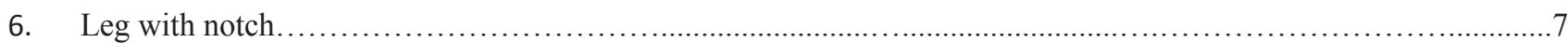

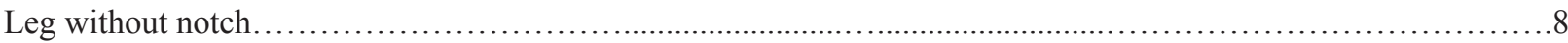

7. Leg long and spiny (Fig. 3I), antennae long and composed of series of cylindrical segments ...................arabidae

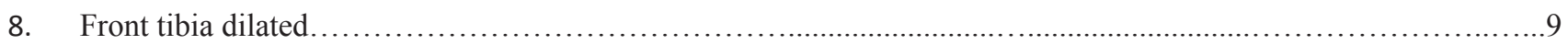

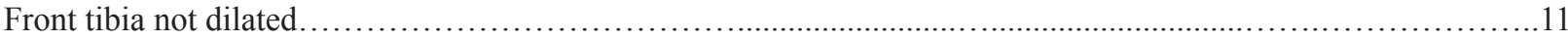

9. Antennae with plate like structure forming compound club (Figs. 3A, E)........................................Scarabaeidae 
Antennae without plate like structure.

10. Beetle often very heavy; elbowed antennae present (Fig. 3C). Curculionidae

11. Tarsal claw clefted with hair (Fig. 3O) Cerambycidae Tarsal claw toothed at base...

Coccinelidae

\section{Heteroptera}

12. Hemelytra present, anterior portion of hemelytra contains two closed cells (Fig.1L)

Miridae

Without punctae on hemelytra.

13. Long hairy leg....

Pentatomidae

Leg with spine...... Orthoptera..... 24, Homoptera. ... .14

14. Hind tibia with 1 or 2 rows of spines, hind coxae transverse Cicadellidae

15. With membranous or parchment- like wings. . .16

Wing with comparatively less longitudinal veins.

16. Wings with simple venation, few cross veins, can often distinguish parts of $\mathrm{R}, \mathrm{Cu}, \mathrm{M}$ or Oral veins (Figs. 2A, I, ) ................................True flies

More complicated venation, often with numerous cross veins, more difficult to determine identification of specific veins (Fig. 2 F)

Odonata

\section{Diptera, Hymenoptera, Thysanoptera and Trichoptera}

17. Anal vein straight gently curved; the anal cell closed at or before wing margin; hind tibia with or without apical spur; abdomen robust; eye usually bare; head somewhat triangular (Fig 1G). Tabanidae

Not as above. ...

18. Wings usually with fewer than seven longitudinal veins (Fig 2I).

Cecidomyiidae

All veins equally heavy and more than 6-10 main veins.

19. Wings with scales and cross vein at about the middle, antennae pilose type, long slender, hairy leg (Figs. 2E, Fig. 3B)

Wings without scale

20. Housefly like (Fig.2G)

Muscidae

Wings somewhat like Housefly but $\mathrm{R}$ and $\mathrm{Cu}$ veins structure differ, row of fine hairs on the costal margin present (Fig 2D). Calliphoroidae

Wings covered with relatively long hairs, cross veins absent, 10-11 veins run to the margin (Fig.2C)..Psychophidae False margin.

21. Venation are sharply conspicuous and move more or less parallel with the border (Fig.2H) Syrphidae

22. Wings with many fairly long hair attached along the veins Trichoptera Abdomen is highly constricted (Fig. 1F), wings often with tiny hairs throughout membranes, stigma (dark spot on anterior part of front wing) often present on front win Hymenoptera. .23

Wings long and narrow, vein less or with only 1 or 2 veins and fringed with long hairs, minute insect (Fig.1C, E, Fig. 3C)........ Thysanoptera .Thripidae

\section{Hymenoptera}

23. Wing with large cells, recurrent vein, abdomen constricted .Ichenomonidae Legs show pollen- transporting apparatus (Fig. $3 \mathrm{H}$ ). Apidae

\section{Orthoptera}

24. Hind tibia with large spines at tip (Fig. 3M) Acrididae Front femora with 2 or 3 apical spines, yellow brown wings, antenna Filiform (Fig.3G) Blattidae

25. Very less spines on dorsal surface of front tibia.... Tettigonidae Spines on one side of leg (Fig. 3N) Gryllidae 

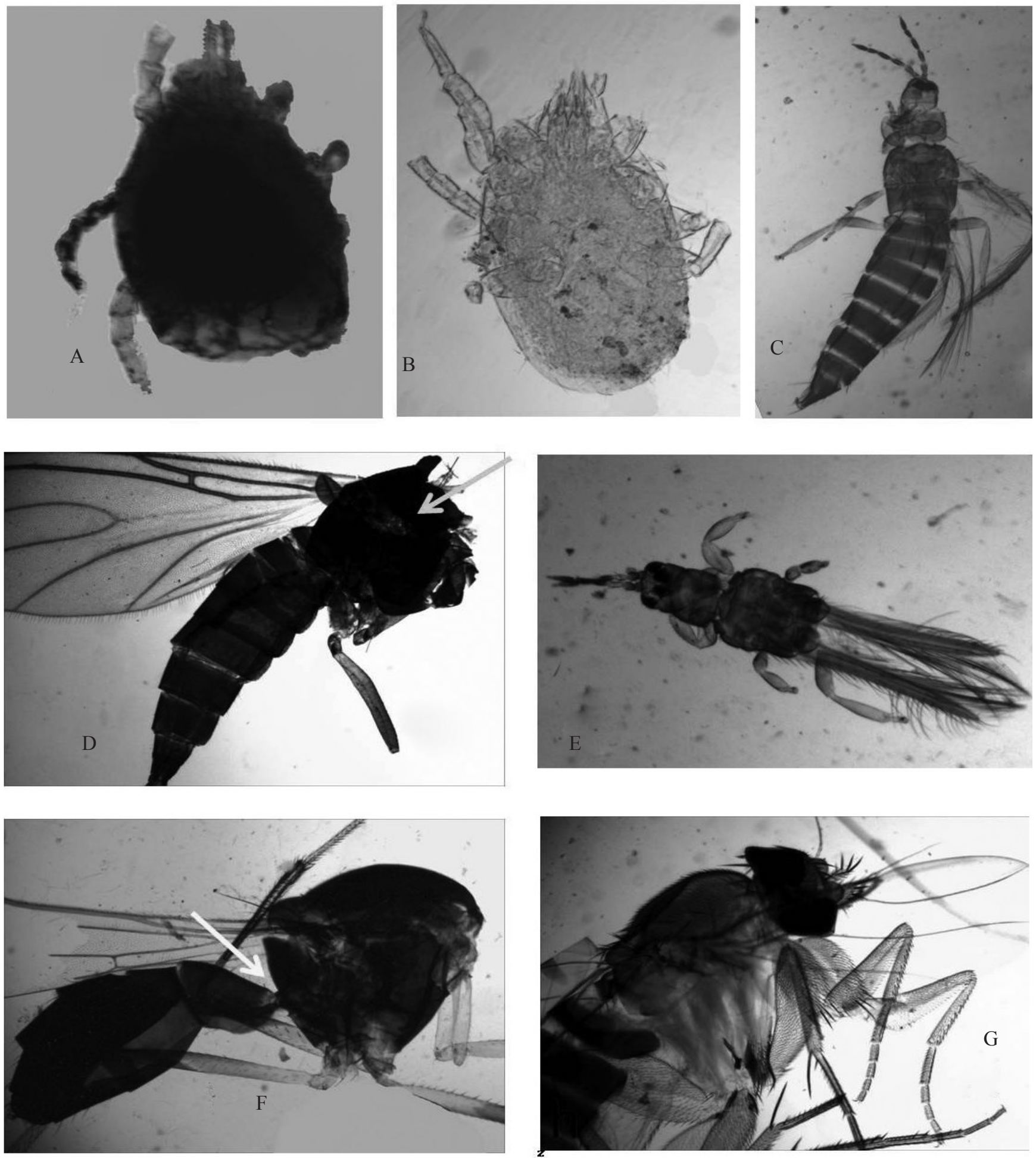

Fig. 1. Insects and Mites found in bat dropppings. A, B. Mites, C,E. Thrip, D. Cecidomyiidae, F. Ichnimonide, G. Tabanidae. 

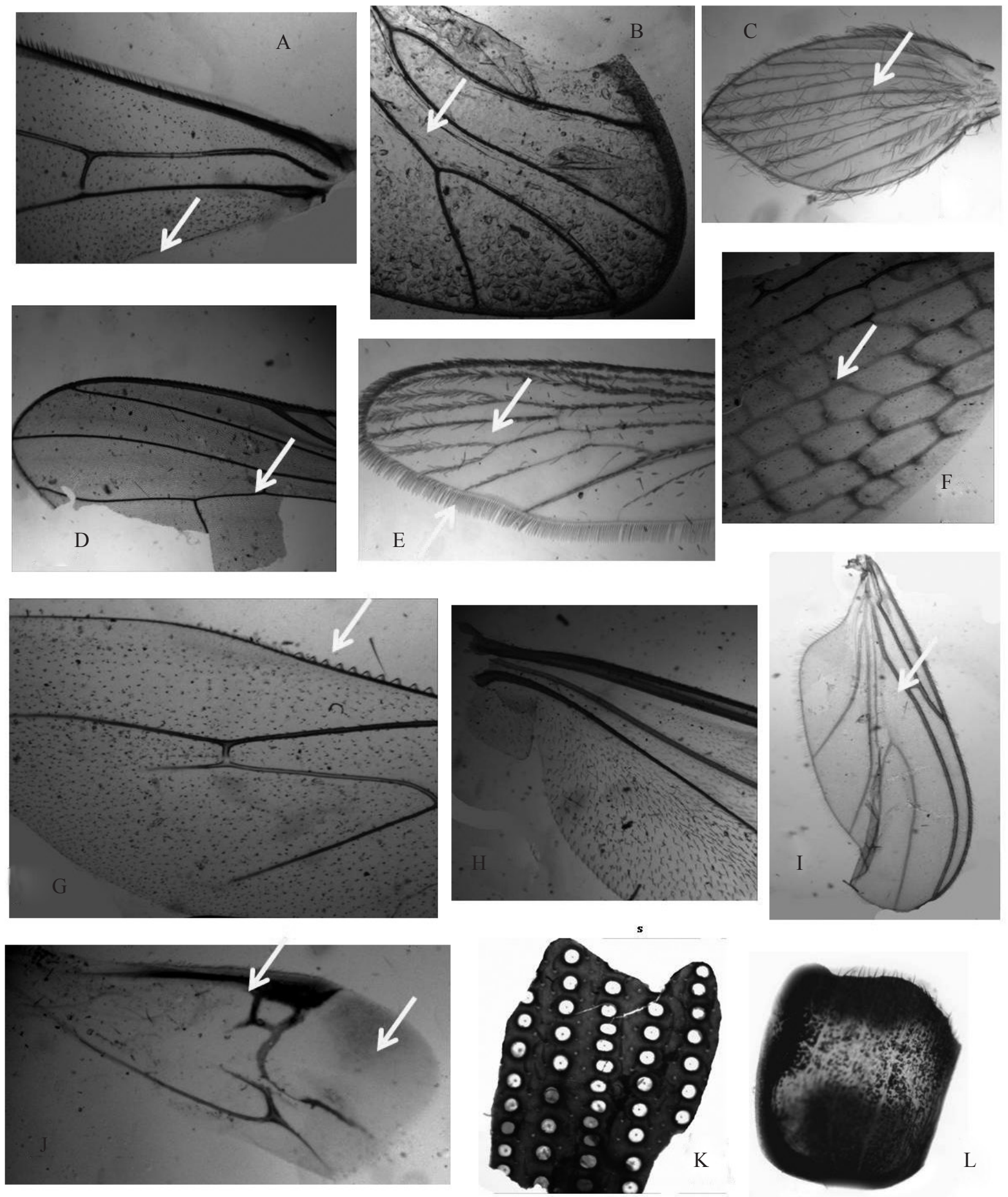

Fig. 2. Wings of insects recovered from bat droppings. A. Diptera, B. Lepidoptera, C. Psychophidae, D. Calliphoridae, E. Culicidae, F. Odonata G. Muscidae, H. Syrphidae, I. Cecidomyiidae J. Miridae, K., L. Beetle (Coleoptera) 

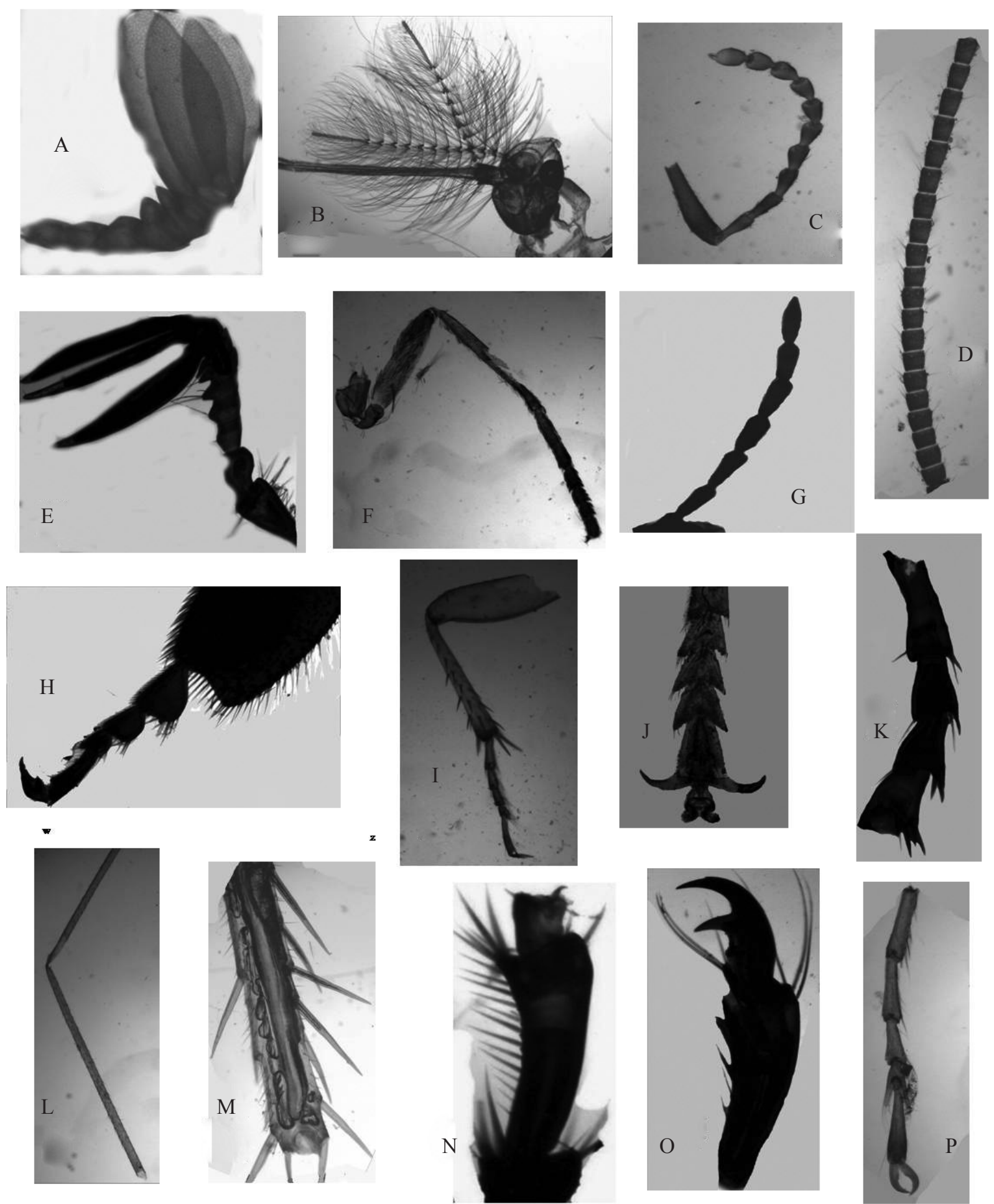

Fig. 3. Antennae and legs of insects/spider collected from bat droppings. A, E. Antennae of Scarabaeidae, B. Antena and mouth parts of Culicidae, C. Antenna of Curculionidae, F. Leg of spider, G. Antennae of Trips (Thysanoptera), D. Filiform antenna of Cockroach (Blattidae), H. leg of Honey bee (Apidae), I. Leg of ground beetle (Carabidae), J, K, O, P. Tarsal segments of beetles (Coleoptera), L. Leg of mosquito (Culicidae), M, N. Leg of grasshoppers and crickets (Orthoptera). 


\section{DISCUSSION AND CONCLUSION}

The dropping analyis of insectivorous bats represents a very good and reliable information on the insect diversity which can be identified at higher taxonomic categories viz. Order and Family level. Variety of food identified from two caves- Mahendra cave Pokhara and Nagarjun cave, Kathmandu there is considerable differnces in food types which might be due to difference of insect diversity around two caves, however beetels were the highest in an average in both caves. The environmental factors including temperature play a key role in regulating the insect abundance (Neuza et al. 2009). Some of the food items dominated by a single group of insects in particular season. Different authors published different results from different geographical areas (Kunz et al. 1995; Schulz \& Wainer, 1997, Arlettary et al. 2000) with major proportion of species rich orders such as Coleoptera, Diptera, Hymenoptera, Orthoptera and Lepidoptera. But the present study represents very low number of Lepidoptera. Although insectivorous bats eat flying insects, few samples contained flightless arthropods such as mites and spiders. The former one may come along the insects infected with mites but spiders migth be picked up from the spiderweb during the flight which was also represented in significant number in some studies (Whitaker \& Lawhead, 1992).

Although the diversity pattern of insect food items in both caves similar but the variety of insect food varies with changing geographical locations of two caves. It is obviously that the insect abundance and diversity varies according to elevation range in Nepal.

\section{ACKNOWLEDGEMENTS}

Ms. Santosh Pokhrel acknowledges the Head of the Central Department of Zoology, Tribhuvan University for providing laboratory and imaging facilities in the department. She would like to thank the Bat Conservation Committee members of Nagarjun and Mahendra caves for providing their support in sample collection and Small Mammal Conservation and Research Foundation (SMCRF), New Baneshwor, Nepal for providing financal support for her field work. Finally, thanks to Mr. Sanjan Thapa for helping in identification of bats in the field.

\section{REFERENCES}

Acharya, P.R. 2006. Distribution of roosting and survival threats of bats in Pokhara valley with reference to species and population survey at Chamere Gupha. M.Sc. Thesis. Central Department of Zoology, Tribhuvan University, Kathmandu, Nepal.
Ades, G.W.J. 1995. A comparative ecological study of Insectivorous bats (Hipposideridae, Vespertillonidae and Rhinolophidae) in Hong Kong, with special reference to dietary seasonality. University of Hong Kong PhD in Ecology and Biodiversity. Thesis abstract.

Arlettary, R., Godat, S. and Meyer, H. 2000. Competition for food by expanding Pipistrelle bat population (Pipistrellus pipistrellus) might contribute to the decline of lesser horseshoe bats (Rhinolophus hipposideros). Biology Conservation 93: 55-60.

Baral, H.S. and Shah, K.B. 2008. Wild mammals of Nepal. Himalayan Nature, Kathmandu.

Bingham, C.T.C 1975. Fauna of British India: Hymenoptera, Volume 1. Today and Tomorrow's Printers and Publishers, New Delhi, India.

Borrer, D.J., Delong, D.M. and Triplehorn, C.A. 1981. An Introduction to the Study of Insect. $5^{\text {th }} \mathrm{ed}$. CBS College Publishing. Holt, Rinehart and Winston.

Distant, W.L. 1977. Fauna of British India: Rhynchota vol 5: Heteroptera. Today and Tomorrow's Printers and Publishers, New Delhi, India.

Giri, B.K. 2009. Habitat suitability mapping and species identification of Chiroptera: A case study from Kaski District. M.Sc. Thesis. Central Department of Zoology, Tribhuvan University, Kathmandu, Nepal.

Hutson, A.M., Mickleburgh, S.P. and Racey, P.A. 2001. Microchiroptera Bats: Global Status, Survey and Conservation Action Plan. International Union for Conservation of Nature and Natural Resources. Chiroptera Specialist Group (IUCN|SSC). Gland, Switzerland: 258.

Jacoby, M. 1975. Fauna of British India: Coleoptera, Vol. 1. Chrysomelidae. Today and Tomorrow's Printers and Publishers, New Delhi, India.

Jnawali, S.R., Baral, H.S., Lee, S., Acharya. K.P., Upadhyay, G.P., Pandey, M., Shrestha, R., Joshi, D., Lamichhane, B.R., Griffiths, J., Khatiwada, A.P., Subedi, N. and Amin, R. (compilers). 2011. The status of Nepal's Mammals: The National Red List Series. Department of National Park and Wildlife Conservation, Kathmandu, Nepal.

Jones, G., Jacobs, D.S., Kunz, T.H., Wilig, M.R. and Racey, P.A. 2009. The importance of bats as bioindicators. Endangered Species Research 8: 93-115

Koju, N.P. 2008. Population status, general behavior and threats of Flying Fox in Sallaghari, Bhaktapur, Nepal. M. Sc. Thesis. Central Department of 
Zoology, Tribhuvan University, Kathmandu, Nepal.

Kunz, T., H. and Whitaker, J.O. 1983. An evaluation of fecal analysis for determining food habits of insectivorous bats. Canadian Journal of Zoology. 61: 1317-1321.

Lacki, M.J., Johnson J.S., Dodd L.E. and Baker M.D. 2007. Prey consumption of insectivorous bats in coniferous forest of North Central Idoho. Journal of Northern Science 81(3): 199-205.

Malla, R. 2000. Diet analysis of Hipposideros armiger and Rhinolophus pusillus of Nagarjun Cave. M.Sc. Thesis. Central Department of Zoology, Tribhuvan University, Kathmandu, Nepal.

McAney, M.C., Shiel, C., Sullivan, C. and Fairley, J. 1991. The analysis of bat drooping. Journal of Mammal Society, Occasional Publication No. 14. London.

Mickleburgh, S.P., Hutson, A.M. and Racey, P.A. 2002. A review of the global conservation status of bats. Oryx 36(1): 18-34.

Neuza, A.P., Marina, R.F., Charles, M.D.O. 2009. Seasonality in insect abundance in the Cerrado of Goias state, Brazil. Journal of Revists Brasileria de Entomologia 55(1): 1-3

Perlik, M.K., McMillan, B.R. and Krenz, J.D. 2012. Food Habitats of the Hoary Bat in an agricultural landscape. Journal of Minnesota Academy of Science 75: 1-6

Richards, O.W. and Davies, R.G. 1977. Imm's General Textbook of Entomology $10^{\text {th }} \mathrm{ed}$. Chapman and Hall Ltd, 2-6 Boundary, Row, London SE1. 8 HN,
UK.

Ross, A. 1967. Ecological aspects of the food habits of insectivorous bats. Proceedings of the Western Foundation of Vertebrate Zoology 42: 66-71.

Schulz, M. and Wainer, J. 1997. Diet of the Golden Tipped Bat (Kerivoula papuensis) from NorthEastern New South Wales, Australia. London Journal of Zoology 243: 653-658.

Shiel, C., McAney C., Sullivan, C. and Fairley, J. 1997. Identification of arthropod fragments in bat droppings. Occasional Publication of the Mammal Society, No. 17.

SMCRF, 2010. Bats of Nepal: A field guide. Small Mammals Conservation Foundation. Kathmandu.

Thapa, S. 2010. An updated checklist of valid bat species of Nepal, Small Mammal Biannual Newsletter of CCINSA, 2 (1): 16-17.

Vanemden, F.I. 1965. Fauna of India, Diptera Volume 7. Baptist Mission Press, Calcutta, India.

Whitaker J.O. 1988. Food habit analysis of insectivorous bats. In: Ecological and Behavioral Methods for the Study of Bats. T. H. Kunz (ed.). Smithsonian Institution Press, Washington, D.C., USA, 1988, pp. 171-189.

Whitaker, J.O. and Lawhead, B. 1992. Food of Myotis lucifugus in a maternity colony in Central Alaska. Journal of Mammal 73: 646-648.

Whitaker, J.O. and Yom-Tov, Y. 2001. The diet of some insectivorous bats from northern Israel. Journal of Mammalian Biology 67: 378-380. 